\title{
Oxidative protein damage is associated with poor grip strength among older women living in the community
}

\author{
Caitlin Howard $^{1}$, Luigi Ferrucci ${ }^{2}$, Kai Sun ${ }^{1}$, Linda P. Fried ${ }^{1}$, Jeremy Walston ${ }^{1}$, Ravi \\ Varadhan $^{1}$, Jack M. Guralnik ${ }^{3}$, and Richard D. Semba ${ }^{1}$ \\ ${ }^{1}$ Johns Hopkins Medical Institutions, Baltimore ${ }^{2}$ Longitudinal Studies Section, Clinical Research Branch, \\ National Institute on Aging, Baltimore ${ }^{3}$ Epidemiology, Demography and Biometry Branch, National Institute \\ on Aging, Bethesda, Maryland
}

\begin{abstract}
Grip strength, an indicator of muscle strength, has been shown to be a predictor of poor outcomes among older adults. Protein carbonylation, an indicator of oxidative damage to proteins, leads to cellular dysfunction and a decline in tissue function. Oxidative stress has been implicated in the pathogenesis of sarcopenia. The objective was to determine whether serum protein carbonyl concentrations are associated with grip strength in older women living in the community. A crosssectional study was conducted in 672 women, aged 65 and older, from the Women's Health and Aging Study (WHAS) I, the one-third most disabled women residing in the community in Baltimore, MD. Protein carbonyl and grip strength were measured in each patient. In a multivariate analysis adjusting for age, race, body mass index, and Mini-Mental Status Examination score, protein carbonyls $(\mathrm{nmol} / \mathrm{mg})$ were associated with grip strength $(\beta=-6.77, P<0.01)$. The statistical association was unchanged after the analysis adjusted for hypertension, congestive heart failure, and depression. Ordered logistic regression models adjusted for the above factors showed that protein carbonyls are associated with increased odds of being in the lower quartiles of grip strength (odds ratio $8.74,95 \%$ confidence interval $1.06-71.89, P=0.043$ ). These results suggest oxidative protein damage is independently associated with low grip strength among older women living in the community. Increased oxidative stress may be contributing to loss of muscle strength in older adults.
\end{abstract}

\section{Keywords}

aging; sarcopenia; interleukin-6; oxidative stress; protein carbonyls

\begin{abstract}
Muscle strength and muscle mass both deteriorate with age $(15,17)$. The cause of this decrease in muscle strength and mass is not well characterized. In the human skeletal muscle, proteins, DNA, and lipids are damaged by reactive oxygen species during oxidative stress. The levels of these damaged macromolecules and lipids increase with age $(6,11,14,18)$. Protein carbonyls are known markers of oxidative stress and accumulate with aging (22). Protein carbonylation leads to cellular dysfunction and a decline in tissue function and is involved in the pathogenesis of sarcopenia (5).
\end{abstract}

Handgrip strength is strongly correlated with other measures of muscle strength and therefore is often considered representative of total body muscle strength (21). In healthy, middle-aged

Address for reprint requests and other correspondence: C. Howard, 550 N. Broadway, Suite 700, Baltimore, MD 21205 (e-mail: chowar17@jhmi.edu). 
men, grip strength at baseline was associated with incident disability and long-term mortality $(19,20)$. Grip strength was also a predictor of cause-specific and total mortality among older disabled women (21). Despite this strong evidence, the mechanism that connects muscle strength and mortality is still a matter of speculation. We hypothesized that poor grip strength in older adults is associated with higher oxidative stress, as reflected by oxidative damage to proteins. To address this hypothesis, we measured serum protein carbonyl concentrations and grip strength among moderately to severely disabled older women living in the community in Baltimore, MD.

\section{Materials and Methods}

A cross-sectional study was conducted among 672 women, aged 65 and older, from the Women's Health and Aging Studies (WHAS) I, representative of the one-third most disabled women residing in the community in Baltimore, MD. Participants were recruited from an agestratified random sample of women aged $65 \mathrm{yr}$ and older selected from Medicare enrollees residing in 12 contiguous zipcode areas in Baltimore (7). Women were screened to identify self-reported physical disability that was categorized into four domains. The domains of disability were ascertained in a 20 - to 30 -min home interview that included questions related to 1 ) mobility and exercise tolerance, i.e., walking for one-quarter of a mile, walking up 10 steps without resting, getting in and out of bed or chairs; 2) upper extremity function, i.e., raising your arms up over your head, using your fingers to grasp or handle, lifting or carrying something as heavy as 10 pounds; 3 ) higher functioning tasks (a subset of instrumental activities of daily living, not including heavy housework, i.e., using the telephone, doing light housework, preparing your own meals, shopping for personal items); and 4) basic self-care tasks (a subset of non-mobility-dependent activities of daily living, i.e., bathing or showering, dressing, eating, using the toilet). WHAS I enrolled the one-third most disabled women ages $65 \mathrm{yr}$ and older, those with disability in two or more domains. Of the 1,409 women who met study eligibility criteria, 1,002 agreed to participate in the study in 1992. There were no major differences in sociodemographic or reported health characteristics between eligible participants and those who declined to participate (7).

Standardized questionnaires were administered in the participant's home by trained interviewers. Mini-Mental Status Examination (MMSE) was recorded (7). Race was assessed in a questionnaire as black, white, or other; current smoking as "yes" or "no"; and education as $0-8,9-11,12$, or more than $12 \mathrm{yr}$ as the highest level of formal education achieved. Two weeks later, a trained registered full-time study nurse conducted an examination of each study participant in her home, using a standardized protocol that included physical performance measures and a standardized physical examination. Approximately $75 \%$ of women also consented to phlebotomy performed during a separate visit by a trained phlebotomist who followed a standardized protocol. Further details on the methods and sampling design of the WHAS studies are published elsewhere (7).

There were 1,002 women enrolled in WHAS I, of whom 672 women participated in the blood drawing and had serum protein carbonyl measurements at baseline. There were no significant differences in race or body mass index between those who did and did not participate in the blood drawing, but women who did and did not participate in the blood drawing were different by age ( 77.4 vs. 80.7 yr old, respectively; $P<0.0001)$. Nonfasting blood samples were obtained by venipuncture between 9 AM and 2 PM. Processing, aliquoting, and freezing were carried out at the Core Genetics Laboratory of The Johns Hopkins University School of Medicine following a standardized protocol. Blood samples were delivered to Quest Diagnostics Laboratories (Teterboro, $\mathrm{NJ}$ ) and in part stored continuously at $-70^{\circ} \mathrm{C}$ until the time of analyses for serum protein carbonyls and serum IL-6. Written informed consent was obtained from all 
subjects. The protocol was approved by the Institutional Review Board of the Johns Hopkins Medical Institutions.

Handgrip strength test was assessed by the nurse using a JAMAR hand dynamometer (model BK-7498, Fred Sammons, Brookfield, IL). Testing was done with the participant in a seated position and the elbow flexed at $90^{\circ}$. Three measurements were taken for each hand, and the participant was encouraged to exhibit the best force possible. The handgrip strength test was completed by 919 of the 1,002 women enrolled in the study. The reasons for not completing the handgrip strength were as follows: systolic blood pressure of $180 \mathrm{mmHg}$ or greater or diastolic pressure of $110 \mathrm{mmHg}$ or greater $(n=55)$, pain $(n=10)$, tester or participant felt the test was unsafe $(n=11)$, participant refusal $(n=2)$, and other $(n=5)$. Women were excluded from the grip strength test if they had recent worsening of pain or arthritis in the wrist or hand, or tendonitis.

Serum protein carbonyls were measured using a commercial ELISA (Zentech PC Test, Protein Carbonyl Enzyme Immuno-Assay Kit, Biocell, Papatoetoe, NZ). Protein carbonyls are stable under long-term storage at $-70^{\circ} \mathrm{C}$ (4). The assay has a minimum detectability of $0.02 \mathrm{nmol} /$ $\mathrm{mg}$ protein, which is well below that range found in healthy human controls. Intra-assay and interassay coefficients of variation for protein carbonyl measurements were $10.1 \%$ and $18.2 \%$. Serum IL-6 was measured using a commercial ELISA (Quantikine Human IL-6, R\&D Systems, Minneapolis, MN).

Descriptive statistics were used to characterize the study population and to describe biochemical measurements of serum protein carbonyl and grip strength. Body mass index was categorized as underweight $\left(<18.5 \mathrm{~kg} / \mathrm{m}^{2}\right)$, normal range $\left(18.5-24.9 \mathrm{~kg} / \mathrm{m}^{2}\right)$, overweight $(\geq 25-$ $\left.29.9 \mathrm{~kg} / \mathrm{m}^{2}\right)$, and obese $\left(\geq 30 \mathrm{~kg} / \mathrm{m}^{2}\right)$, according to World Health Organization criteria (9). Linear regression analysis was used to examine the relationship between serum protein carbonyl and other factors with grip strength as a continuous outcome variable. Ordered logistic regression was used to examine the relationship between serum protein carbonyls and grip strength in quartiles, where the 25th, 50th, and 75th percentiles of grip strength were 14.8, 17.8, and $21.3 \mathrm{~kg}$, respectively.

\section{Results}

Baseline demographic and disease characteristics of the 672 women from WHAS I participating in the study are described in Table 1. The mean age (SD) was 77.4 yr (SD 7.9). The mean serum protein carbonyl concentration was $0.098 \mathrm{nmol} / \mathrm{mg}$, and the mean grip strength was $18.1 \mathrm{~kg}$ (SD 5.0).

Table 2 displays the univariate linear regression model used to examine the relationship between serum protein carbonyl levels, disease, and other risk factors associated with grip strength. Grip strength was significantly associated with age, race, smoking status, body mass index, MMSE, serum protein carbonyls, hypertension, congestive heart failure, and depression. Grip strength was not significantly associated with education, coronary artery disease, peripheral artery disease, stroke, osteoarthritis, diabetes mellitus, chronic obstructive pulmonary disease, or cancer.

The multivariate analysis of the association between serum protein carbonyl and grip strength is displayed in Table 3. After an analysis adjusting for age, race, body mass index, and MMSE (model 1 ), protein carbonyl levels were significantly associated with grip strength $(P<0.01)$. Addition of hypertension, congestive heart failure, and depression to the analysis (model 2) produced similar results $(P<0.05)$. 
The relationship between grip strength and serum protein carbonyls was also examined using ordered logistic regression (Table 4). The outcome was grip strength, expressed as an ordinal variable with four levels in order, created by quartile cutoff points of $14.8,17.8$, and $21.3 \mathrm{~kg}$. In multivariate analyses adjusting for age, race, IL-6, body mass index, and MMSE (model 1 ), protein carbonyls were strongly associated with the lower quartiles of grip strength [odds ratio (OR) $10.85, P=0.028$ ]. Addition of hypertension, congestive heart failure, and depression to the analysis (model 2) produced similar results (OR 8.74, $P=0.043$ ). The interpretation of the OR here is that one unit increase in protein carbonyls is associated with a higher odds of being in the lower quartiles compared with higher quartiles of grip strength.

\section{Discussion}

The present study shows that high serum protein carbonyls are independently associated with poor grip strength among moderately to severely disabled older women living in the community. These results are consistent with the idea that reactive oxygen species may contribute to a decline in muscle function with aging (10). Accumulation of reactive oxygen species throughout life is known to contribute to aging (8). The mechanism by which reactive oxygen species accumulate and contribute to the aging of muscles involves the insufficient function of the respiratory chain, as well as mutations in mitochondrial DNA (13).

The oxidative capacity of human muscles has been characterized between younger and older adults (3) and is shown to decrease with age and muscle mass. In humans, elevated serum protein carbonyls have been described in the elderly compared with younger adults $(2,12,16)$. Studies have shown that elevated serum protein carbonyls are associated with the age-induced decline in muscle performance (1). Grip strength, an indicator of muscle strength, has been associated with mortality and disability $(19,20)$. Previous studies, however, have not characterized the relationship between grip strength and serum protein carbonyl levels. The association between protein oxidation and poor grip strength has clinical relevance since there are modifiable risk factors that may affect oxidative stress, such as smoking; dietary intake of carotenoids, ascorbate, selenium, plant polyphenols, and other antioxidants; and exercise.

The present study was conducted among older moderate to severely disabled women living in the community, and it is not clear whether serum protein carbonyls and grip strength will be significantly associated in younger populations, among less disabled older women, and among men. Further studies are needed to expand these investigations to other populations. In addition, oxidative protein damage was used as the only indicator of oxidative stress in the present study. Indicators of oxidative damage to lipids and oxidative damage to DNA could complement these investigations, and such laboratory studies remain to be done.

In summary, serum protein carbonyls were independently associated with grip strength, a finding that is consistent with the presumed biological mechanism by which the accumulation of reactive oxygen species can contribute to sarcopenia. These findings may contribute to the determination of the underlying mechanism of aging and the oxidative pathway.

\section{Acknowledgements}

Grants: This research was supported by National Institutes of Health Grant R01-AG-027012 and the Johns Hopkins Older Americans Independence Center Grant P30-AG-021334.

\section{References}

1. Barreiro E, Coronell C, Lavina B, Ramirez-Sarmiento A, Orozco-Levi M, Gea J. Aging, sex differences, and oxidative stress in human respiratory and limb muscles. Free Radic Biol Med 2006;41:797-809. [PubMed: 16895800] 
2. Beal MF. Oxidatively modified proteins in aging and disease. Free Radic Biol Med 2002;32:797-803. [PubMed: 11978481]

3. Conley KE, Jubrias SA, Esselman PC. Oxidative capacity and ageing in human muscle. J Physiol 2000;526:203-210. [PubMed: 10878112]

4. Dalle-Donne I, Rossi R, Giustarini D, Milzani A, Colombo R. Protein carbonyl groups as biomarkers of oxidative stress. Clin Chim Acta 2003;329:23-38. [PubMed: 12589963]

5. Fulle S, Protasi F, Di Tano G, Pietrangelo T, Beltramin A, Boncompagni S, Vecchiet L, Fano G. The contribution of reactive oxygen species to sarcopenia and muscle ageing. Exp Gerontol 2004;39:1724. [PubMed: 14724060]

6. Gianni P, Jan KJ, Douglas MJ, Stuart PM, Tarnopolsky MA. Oxidative stress and the mitochondrial theory of aging in human skeletal muscle. Exp Gerontol 2004;39:1391-1400. [PubMed: 15489062]

7. Guralnik, JM.; Fried, LP.; Simonsick, EM.; Kasper, D.; Lafferty, ME. The Women's Health and Aging Study: Health and Social Characteristics of Older Women with Disability. Bethesda, MD: National Institute on Aging; 1995. NIH Publication No. 95-4009

8. Harman D. The aging process. Proc Natl Acad Sci USA 1981;78:7124-7128. [PubMed: 6947277]

9. James PT, Leach R, Kalamara E, Shayeghi M. The worldwide obesity epidemic. Obesity Res 9 Suppl 2001;4:228S-233S.

10. Leeuwenburgh C, Hansen P, Shaish A, Holloszy JO, Heinecke JW. Markers of protein oxidation by hydroxyl radical and reactive nitrogen species in tissues of aging rats. Am J Physiol Regul Integr Comp Physiol 1998;274:R453-R461.

11. Lim PS, Cheng YM, Wei YH. Increase in oxidative damage to lipids and proteins in skeletal muscle of uremic patients. Free Radic Res 2002;36:295-301. [PubMed: 12071348]

12. Kasapoglu M, Özben T. Alterations of antioxidant enzymes and oxidative stress markers in aging. Exp Gerontol 2001;36:209-220. [PubMed: 11226737]

13. Kovalenko SA, Kopsidas G, Islam MM, Heffernan D, Fitzpatrick J, Caragounis A, Gingold E, Linnane AW. The age-associated decrease in the amount of amplifiable full-length mitochondrial DNA in human skeletal muscle. Biochem Mol Biol Int 1998;46:1233-1241. [PubMed: 9891857]

14. Mecocci P, Fanó G, Fulle S, MacGarvey U, Shinobu L, Polidori MC, Cherubini A, Vecchiet J, Senin U, Beal MF. Age-dependent increases in oxidative damage to DNA, lipids, and proteins in human skeletal muscle. Free Radic Biol Med 1999;26:303-308. [PubMed: 9895220]

15. Morley JE, Baumgartner RN, Roubenoff R, Mayer J, Nair KS. Sarcopenia. J Lab Clin Med 2001;137:231-243. [PubMed: 11283518]

16. Mutlu-Türkoğlu Ü, İlhan E, Öztezcan S, Kuru A, Aykaç-Toker G, Uysal M. Age-related increases in plasma malondialdehyde and protein carbonyl levels and lymphocyte DNA damage in elderly subjects. Clin Biochem 2003;36:397-400. [PubMed: 12849873]

17. Nair KS. Aging muscle. Am J Clin Nutr 2005;81:953-963. [PubMed: 15883415]

18. Pansarasa O, Bertorelli L, Vecchiet J, Felzani G, Marzatico F. Age-dependent changes of antioxidant activities and markers of free radical damage in human skeletal muscle. Free Radic Biol Med 1999;27:617-622. [PubMed: 10490283]

19. Rantanen T, Guralnik JM, Foley D, Masaki K, Leveille S, Curb JD, White L. Midlife hand grip strength as a predictor of old age disability. JAMA 1999;281:558-560. [PubMed: 10022113]

20. Rantanen T, Harris T, Leveille SG, Visser M, Foley D, Masaki K, Guralnik JM. Muscle strength and body mass index as long-term predictors of mortality in initially healthy men. J Gerontol A Biol Sci Med Sci 2000;55:M168-M173. [PubMed: 10795731]

21. Rantanen T, Volpato S, Ferrucci L, Heikkinen E, Fried LP, Guralnik JM. Handgrip strength and cause-specific and total mortality in older disabled women: exploring the mechanism. J Am Geriatr Soc 2003;51:636-641. [PubMed: 12752838]

22. Stadtman ER. Protein oxidation and aging. Free Radic Res 2006;40:1250-1258. [PubMed: 17090414] 
Table 1

Characteristics of women in the Women's Health and Aging Study I at baseline

\begin{tabular}{|c|c|}
\hline Characteristic & Mean (SD) or \% \\
\hline Age, yr & $77.4(7.9)$ \\
\hline Race (white), \% & 72.77 \\
\hline Education $<12 \mathrm{yr}, \%$ & 64.18 \\
\hline Current smokers, $\%$ & 10.42 \\
\hline \multicolumn{2}{|l|}{ Body mass index, $\%$ in each subgroup } \\
\hline$<18.5 \mathrm{~kg} / \mathrm{m}^{2}$ & 3.44 \\
\hline $18.5-24.9 \mathrm{~kg} / \mathrm{m}^{2}$ & 23.61 \\
\hline $25.0-29.9 \mathrm{~kg} / \mathrm{m}^{2}$ & 36.39 \\
\hline$\geq 30 \mathrm{~kg} / \mathrm{m}^{2}$ & 36.56 \\
\hline MMSE score $<24, \%$ & 16.82 \\
\hline Serum protein carbonyls, $\mathrm{nmol} / \mathrm{mg}$ & 0.098 \\
\hline Grip strength, $\mathrm{kg}$ & $18.1(5.0)$ \\
\hline Hypertension, \% & 56.78 \\
\hline Coronary heart disease, $\%$ & 23.21 \\
\hline Congestive heart failure, $\%$ & 10.57 \\
\hline Peripheral artery disease, $\%$ & 20.39 \\
\hline Stroke, \% & 5.95 \\
\hline Osteoarthritis, \% & 53.27 \\
\hline Diabetes mellitus, $\%$ & 16.96 \\
\hline Chronic obstructive pulmonary disease, $\%$ & 29.32 \\
\hline Depression, $\%$ & 16.96 \\
\hline Cancer, $\%$ & 11.31 \\
\hline
\end{tabular}

Values are means (SD) for continuous variables or are percentages as noted; $n=672$ women. MMSE, Mini-Mental Status Examination. 
Table 2

Univariate linear regression models of serum protein carbonyls and other risk factors with grip strength

\begin{tabular}{|c|c|c|c|}
\hline Characteristic & $\boldsymbol{\beta}$ & SE & $P$ \\
\hline Age (yr) & -0.235 & 0.023 & $<0.0001$ \\
\hline Race (white) & -2.061 & 0.426 & $<0.0001$ \\
\hline Education $<12 \mathrm{yr}$ & -0.375 & 0.403 & 0.35 \\
\hline Current smokers (\%) & 1.421 & 0.629 & 0.024 \\
\hline \multicolumn{4}{|l|}{ Body mass index ${ }^{*}$} \\
\hline$<18.5 \mathrm{~kg} / \mathrm{m}^{2}$ & -2.46 & 1.11 & 0.0260 \\
\hline $25.0-29.9 \mathrm{~kg} / \mathrm{m}^{2}$ & 1.38 & 0.47 & 0.0034 \\
\hline$\geq 30 \mathrm{~kg} / \mathrm{m}^{2}$ & 2.62 & 0.47 & $<0.0001$ \\
\hline MMSE & -1.719 & 0.512 & 0.0008 \\
\hline Serum protein carbonyls $(\mathrm{nmol} / \mathrm{mg})$ & -6.068 & 2.841 & 0.03 \\
\hline Hypertension & 0.913 & 0.339 & 0.02 \\
\hline Coronary heart disease & -0.239 & 0.457 & 0.61 \\
\hline Congestive heart failure & -1.940 & 0.623 & 0.002 \\
\hline Peripheral artery disease & -0.363 & 0.478 & 0.45 \\
\hline Stroke & -1.240 & 0.815 & 0.13 \\
\hline Osteoarthritis & 0.142 & 0.387 & 0.71 \\
\hline Diabetes mellitus & 0.679 & 0.514 & 0.19 \\
\hline Chronic obstructive pulmonary disease & 0.170 & 0.424 & 0.689 \\
\hline Depression & -1.772 & 0.510 & 0.0005 \\
\hline Cancer & -0.770 & 0.610 & 0.21 \\
\hline
\end{tabular}

$n=672$ women.

Reference category is body mass index of $18.5-24.9 \mathrm{~kg} / \mathrm{m}^{2}$. 
Table 3

Multivariate linear regression models of serum protein carbonyls and other risk factors with grip strength

\begin{tabular}{|c|c|c|c|}
\hline Characteristic & $\beta$ & SE & $P$ \\
\hline \multicolumn{4}{|c|}{ Model 1} \\
\hline Protein carbonyls (nmol/mg) & -6.77 & 2.58 & 0.0089 \\
\hline Age (yr) & -0.19 & 0.02 & $<0.0001$ \\
\hline Race (white) & -1.70 & 0.40 & $<0.0001$ \\
\hline \multicolumn{4}{|l|}{ Body mass index ${ }^{*}$} \\
\hline $18.5 \mathrm{~kg} / \mathrm{m}^{2}$ & -1.89 & 1.04 & 0.069 \\
\hline $25.0-29.9 \mathrm{~kg} / \mathrm{m}^{2}$ & 1.26 & 0.44 & 0.004 \\
\hline$\geq 30 \mathrm{~kg} / \mathrm{m}^{2}$ & 1.53 & 0.45 & 0.0007 \\
\hline MMSE & -0.89 & 0.49 & 0.07 \\
\hline \multicolumn{4}{|c|}{ Model 2} \\
\hline Protein carbonyls (nmol/mg) & -5.83 & 2.57 & 0.024 \\
\hline Age (yr) & -0.18 & 0.02 & $<0.0001$ \\
\hline Race (white) & -1.53 & 0.41 & 0.0002 \\
\hline Current smoking & 0.91 & 0.58 & 0.12 \\
\hline \multicolumn{4}{|l|}{ Body mass index ${ }^{*}$} \\
\hline$<18.5 \mathrm{~kg} / \mathrm{m}^{2}$ & -1.95 & 1.03 & 0.06 \\
\hline $25.0-29.9 \mathrm{~kg} / \mathrm{m}^{2}$ & 1.21 & 0.44 & 0.006 \\
\hline$\geq 30 \mathrm{~kg} / \mathrm{m}^{2}$ & 1.59 & 0.45 & 0.0005 \\
\hline MMSE & -0.68 & 0.49 & 0.16 \\
\hline Hypertension & 0.22 & 0.36 & 0.54 \\
\hline Congestive heart failure & -1.33 & 0.57 & 0.02 \\
\hline Depression & -1.38 & 0.47 & 0.003 \\
\hline
\end{tabular}


Table 4

Multivariate ordered logistic regression models of serum protein carbonyls and other risk factors with grip strength

\begin{tabular}{|c|c|c|c|}
\hline Variable & OR & $95 \% \mathrm{CI}$ & $P$ \\
\hline \multicolumn{4}{|c|}{ Model 1} \\
\hline Protein carbonyls (nmol/mg) & 10.85 & $1.30-91.00$ & 0.028 \\
\hline IL-6 (pg/ml) & 1.06 & $1.00-1.13$ & 0.053 \\
\hline Age (yr) & 1.09 & $1.07-1.11$ & $<0.0001$ \\
\hline Race (white) & 1.80 & $1.30-2.49$ & 0.0004 \\
\hline \multicolumn{4}{|l|}{ Body mass index ${ }^{*}$} \\
\hline$<18.5 \mathrm{~kg} / \mathrm{m}^{2}$ & 1.57 & $0.67-3.69$ & 0.30 \\
\hline $25.0-29.9 \mathrm{~kg} / \mathrm{m}^{2}$ & 0.64 & $0.45-0.90$ & 0.01 \\
\hline$\geq 30 \mathrm{~kg} / \mathrm{m}^{2}$ & 0.56 & $0.39-0.80$ & 0.002 \\
\hline MMSE & 1.21 & $0.82-1.80$ & 0.34 \\
\hline \multicolumn{4}{|c|}{ Model 2} \\
\hline Protein carbonyls (nmol/mg) & 8.74 & $1.06-71.89$ & 0.043 \\
\hline IL-6 (pg/ml) & 1.06 & $1.00-1.13$ & 0.052 \\
\hline Age (yr) & 1.09 & $1.06-1.11$ & $<0.0001$ \\
\hline Race (white) & 1.72 & $1.24-2.39$ & 0.001 \\
\hline Current smoking & 0.74 & $0.46-1.19$ & 0.22 \\
\hline \multicolumn{4}{|l|}{ Body mass index ${ }^{*}$} \\
\hline$<18.5 \mathrm{~kg} / \mathrm{m}^{2}$ & 1.63 & $0.69-3.88$ & 0.27 \\
\hline $25.0-29.9 \mathrm{~kg} / \mathrm{m}^{2}$ & 0.63 & $0.44-0.90$ & 0.01 \\
\hline$\geq 30 \mathrm{~kg} / \mathrm{m}^{2}$ & 0.53 & $0.37-0.76$ & 0.001 \\
\hline MMSE & 1.14 & $0.76-1.69$ & 0.53 \\
\hline Hypertension & 1.01 & $0.75-1.35$ & 0.95 \\
\hline Congestive heart failure & 1.46 & $0.92-2.34$ & 0.11 \\
\hline Depression & 1.79 & $1.22-2.63$ & 0.003 \\
\hline
\end{tabular}

$n=672$ women. OR, odds ratio; CI, confidence interval.

Reference category is body mass index of $18.5-24.9 \mathrm{~kg} / \mathrm{m}^{2}$. 